\title{
Pengaruh CSR Terhadap Nilai Perusahaan Dengan Good Corporate Governance Dan Ukuran Perusahaan Sebagai Variabel Pemoderasi
}

\author{
Didi Firmansyah ${ }^{1}$ \\ Fakultas Ekonomi dan Bisnis \\ Universitas Mataram, Indonesia \\ Email: didi_namaq@yahoo.com
}

\author{
Ni Ketut Surasni2 \\ Fakultas Ekonomi dan Bisnis \\ Universitas Mataram, Indonesia
}

\author{
Sri Pancawati ${ }^{3}$ \\ Fakultas Ekonomi dan Bisnis \\ Universitas Mataram, Indonesia
}

\begin{abstract}
ABSTRAK
Penelitian ini bertujuan untuk mengetahui pengaruh Corporate Social Responsibility (CSR) terhadap nilai perusahaan dengan Good Corporate Governance (GCG) dan ukuran perusahaan sebagai pemoderasi. Populasi penelitian sebanyak 171 perusahaan dengan jumlah sampel sebanyak 110 perusahaan. Teknik analisis data menggunakan MRA (moderated regression analysis). Hasil statistik menunjukkan bahwa CSR berpengaruh terhadap nilai perusahaan dan GCG maupun ukuran perusahaan dapat memoderasi pengaruh antara CSR terhadap nilai perusahaan. Implikasi hasil penelitian ini yaitu jika suatu perusahaan mengharapkan nilai perusahaan meningkat (tinggi), maka diharapkan untuk tetap konsisten dalam membuat laporan CSR yang lebih luas dengan memaksimalkan fungsi pengawasan dewan komisaris baik dalam keadaan posisi laba perusahaan meningkat ataupun menurun serta perusahaan dengan skala kecil maupun besar.
\end{abstract}

Kata Kunci: CSR; GCG; Ukuran Perusahaan; Nilai Perusahaan.

The Effect Of Corporate Social Responsibility On Corporate Value With Good Corporate Governance And Company Size As Moderating Variable

\section{ABSTRACT}

This study aims to determine the effect of Corporate Social Responsibility (CSR) on corporate value with Good Corporate Governance (GCG) and company size as a moderating factor. The study population was 171 companies with a sample of 110 companies. Data analysis techniques using MRA (moderated regression analysis). Statistical results show that CSR influences firm value and GCG as well as company size can moderate the influence of CSR on firm value. The implication of the results of this study is that if a company expects the value of the company to increase (high), it is expected to remain consistent in making a broader CSR report by maximizing the supervisory function of the board of commissioners both in a state where the company's profit position increases or decreases and companies with small and large scale.

Keywords: CSR; GCG; Company Size; The Value Of The Company.

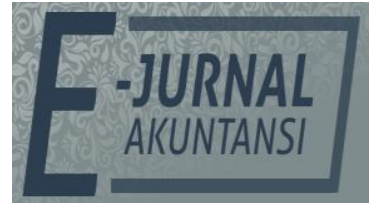

E-JA

e-Jurnal Akuntansi e-ISSN 2302-8556

Vol. 30 No. 1

Denpasar, Januari 2020

Hal. 163-178

Artikel Masuk:

19 Desember 2019

Tanggal Diterima: 8 Januari 2019 


\section{PENDAHULUAN}

Tujuan utama perusahaan berdiri adalah meningkatkan nilai perusahaan melalui peningkatan kemakmuran pemilik atau para pemegang saham. Bila harga saham meningkat, berarti nilai perusahaan meningkat dan kesejahteraan pemilik meningkat. Hal ini sesuai pernyataan Salvatore (2005) bahwa tujuan utama perusahaan yang telah go public adalah meningkatkan kemakmuran pemilik atau para pemegang saham guna memengaruhi nilai perusahaan.

Gapensi (1996) menyatakan bahwa nilai perusahaan sangat penting karena, nilai perusahaan yang tinggi akan diikuti oleh tingginya kemakmuran pemegang saham. Semakin tinggi harga saham, maka semakin tinggi nilai perusahaan. Nilai perusahaan yang tinggi menjadi keinginan para pemilik perusahaan karena dengan nilai yang tinggi menunjukkan kemakmuran pemegang saham yang tinggi pula. Nilai perusahaan dapat dilihat dari kemampuan perusahaan membayar dividen. Besarnya dividen ini dapat memengaruhi harga saham. Apabila dividen yang dibayar tinggi, harga saham cenderung tinggi sehingga nilai perusahaan juga tinggi. Sebaliknya bila dividen yang dibayarkan kecil, harga saham perusahaan tersebut juga rendah. Kemampuan membayar dividen erat hubungannya dengan kemampuan perusahaan memperoleh laba. Jika perusahaan memperoleh laba yang besar, kemampuan membayar dividen juga besar. Oleh karena itu, dengan dividen yang besar akan meningkatkan nilai perusahaan (Matono \& Agus Harjito, 2005). Jensen (2001) menyatakan bahwa untuk memaksimumkan nilai perusahaan dalam jangka panjang, manajer dituntut untuk membuat keputusan yang mempertimbangkan semua stakeholders karena, manajer akan dinilai kinerjanya berdasarkan keberhasilannya mencapai tujuan.

Nilai perusahaan dapat dilihat dari Price Book Value (PBV) yang merupakan perbandingan antara harga saham dengan nilai buku per lembar saham (Ang, 2002). Perusahaan yang baik umumnya mempunyai rasio PBV lebih besar satu $(>1)$, yang menunjukkan bahwa nilai pasar saham lebih besar daripada nilai buku perusahaan. Semakin tinggi nilai rasio PBV semakin tinggi penilaian investor dibandingkan dengan dana yang ditanamkan dalam perusahaan tersebut (Ang, 2002), sehingga semakin besar pula peluang para investor untuk membeli saham perusahaan.

Berikut ini merupakan tabel nilai rata-rata perkembangan Price Book Value (PBV) perusahaan Consumer Goods yang terdaftar di Bursa Efek Indonesia periode 2013 sampai dengan 2017.

Tabel 1.Rata-rata Price Book Value Perusahaan Listed di BEI

\begin{tabular}{llllll}
\hline Rasio & 2013 & 2014 & 2015 & 2016 & 2017 \\
\hline PBV & 5.46 & 5.38 & 2.22 & 5.58 & 5.36 \\
\hline
\end{tabular}

Sumber : Data Penelitian, 2018

Berdasarkan Tabel 1. rata-rata Price Book Value perusahaan manufaktur lebih besar satu $(>1)$. Hal ini menunjukan bahwa nilai pasar saham lebih besar daripada nilai buku perusahaan, sehingga semakin besar pula peluang para investor untuk membeli saham perusahaan tersebut yang merupakan cerminan dari tingginya nilai perusahaan Consumer Goods.

Fenomena tentang tingginya nilai perusahaan manufaktur yang diproksikan dengan PBV menarik untuk dilakukan kajian tentang faktor-faktor 
yang memengaruhi nilai perusahaan. Peningkatan nilai perusahaan juga dipengaruhi oleh Corporate Social Responsibility (CSR) yang merupakan tanggung jawab moral suatu perusahaan terhadap para strategic-stakeholdersnya. Gunawan \& Utami (2008) menyimpulkan bahwa Corporate Social Responsibility berpengaruh positif terhadap nilai perusahaan, artinya semakin banyak perusahaan mengungkapkan item pengungkapan sosialnya dan semakin bagus kualitas pengungkapannya, maka akan semakin tinggi nilai perusahaannya.

Pengungkapan corporate social responsibility merupakan proses komunikasi dampak sosial dan lingkungan dari kegiatan ekonomi organisasi terhadap kelompok khusus yang berkepentingan dan terhadap masyarakat secara keseluruhan. Hal tersebut memperluas tanggung jawab organisasi (khususnya perusahaan) di luar peran tradisionalnya untuk menyediakan laporan keuangan kepada pemilik modal khususnya pemegang saham. Perluasan tersebut dibuat dengan asumsi bahwa perusahaan mempunyai tanggung jawab yang lebih luas dibanding hanya mencari laba untuk pemegang saham (Gray et. al., 1987) dalam (Gunawan \& Utami, 2008).

Owen dalam (Retno \& Priantinah, 2012) mengungkapkan bahwa kasus Enron di Amerika telah menyebabkan perusahaan-perusahaan lebih memberikan perhatian yang besar terhadap pelaporan sustainabilitas dan pertanggungjawaban sosial perusahaan. Isu-isu yang berkaitan dengan reputasi, manajemen risiko, dan keunggulan kompetitif nampak menjadi kekuatan yang mendorong perusahaan untuk melakukan pengungkapan informasi sosial. Perusahaan tidak hanya memandang laba sebagai satu-satunya tujuan dari perusahaan, tetapi ada tujuan yang lainnya, yaitu kepedulian perusahaan terhadap lingkungan karena perusahaan mempunyai tanggung jawab yang lebih luas dibanding hanya mencari laba untuk pemegang saham (Gray et. al., 1987) dalam (Gunawan \& Utami, 2008).

Penelitian Pfleiger et al. (2005) menunjukkan bahwa usaha-usaha pelestarian lingkungan oleh perusahaan akan mendatangkan beberapa keuntungan, di antaranya adalah ketertarikan pemegang saham dan stakeholder terhadap keuntungan yang diperoleh perusahaan akibat pengelolaan lingkungan yang bertanggung jawab. Balbanis et al. (1998) meneliti pengaruh pengungkapan CSR terhadap profitabilitas pada perusahaan yang listing di London Stock Exchange. Hasilnya menunjukan bahwa pengungkapan CSR yang dilakukan perusahaan berpengaruh positif terhadap profitabilitas perusahaan. Handriyani \& Andayani (2013) menyimpulkan bahwa CSR berpengaruh positif terhadap nilai perusahaan. Ahmad, et al. (2003) di Malaysia yang menemukan bukti bahwa pengungkapan CSR mencerminkan usaha-usaha perusahaan untuk meningkatkan image perusahaan dan agar dapat dilihat sebagai perusahaan yang bertanggung jawab. Penelitian ini juga sesuai dengan penelitian yang dilakukan Gunawan \& Utami (2008) yang menyatakan bahwa CSR berpengaruh positif terhadap nilai perusahaan, dimana hasil penelitian tersebut mengindikasikan bahwa CSR merupakan faktor yang mempengaruhi tinggi atau rendahnya nilai perusahaan. Semakin banyak mengungkapkan item pengungkapan sosialnya dan semakin bagus kualitas pengungkapannya, maka akan semakin tinggi nilai perusahaannya. 
Hasil penelitian berbeda dilakukan oleh Nurlela \& Islahuddin (2008); Retno \& Priantinah (2012) yang menyatakan bahwa variabel CSR tidak berpengaruh signifikan terhadap nilai perusahaan. Hal ini diakibatkan karena kualitas pengungkapan CSR pada perusahaan yang terdaftar di BEI untuk tahun penelitian tersebut sangat rendah dan belum mengikuti standar yang dikeluarkan oleh GRI. Dengan demikian kualitas pengungkapan CSR di dalam perusahaan menjadi faktor yang menyebabkan praktik CSR tidak berpengaruh terhadap nilai perusahaan.

Hasil kajian sebelumnya tentang pengaruh CSR terhadap nilai perusahaan menimbulkan pertentangan sehingga menarik untuk dilakukan kajian kembali dengan menambah variabel, yang sifatnya menguatkan hubungan antar dua variabel tersebut. Dalam penelitian ini ingin melakukan analisis tentang pengaruh CSR terhadap nilai perusahaan dengan menguji Good Corporate Governance dan ukuran perusahaan sebagai variabel moderating.

$\mathrm{H}_{1}$ : CSR berpengaruh positif terhadap nilai perusahaan

Teori keagenan menjelaskan mengenai masalah yang akan timbul ketika pemegang saham mengandalkan manajer untuk menyediakan jasa atas nama pemegang saham (Jensen \& Meckling, 1976). Pihak manajer (agen), dengan kewenangan yang dimilikinya bisa bertindak untuk kepentingan pribadinya dan mengorbankan kepentingan para pemegang saham (Trisnantari, 2010). Dengan timbulnya perbedaan kepentingan antara prinsipal dan agen inilah yang melatar belakangi diperlukannya suatu mekanisme pengelolaan perusahaan yang baik. Jensen \& Meckling (1976) berpendapat untuk dapat menyelesaikan masalah keagenan, harus dapat menyelaraskan antara kepentingan agen dengan prinsipal. Untuk mengatasi masalah tersebut perusahaan perlu menerapkan suatu system Tata Kelola Perusahaan atau Good Corporate Governance (GCG).

Penerapan dan pengelolaan Good Corporate Governance yang baik adalah sebuah konsep yang menekankan pentingnya hak pemegang saham untuk memperoleh informasi dengan benar, akurat dan tepat waktu. Disamping itu juga menunjukkan kewajiban perusahaan untuk mengungkapkan semua informasi kinerja keuangan perusahaan secara akurat, tepat waktu dan transparan. Oleh karena itu, baik perusahaan publik maupun tertutup harus memandang Good Corporate Governance (GCG) bukan hanya sebagai aksesoris belaka, namun sebagai upaya peningkatan kinerja dan nilai perusahaan (Tjager, 2003).

Indikator yang sering dipakai dalam berbagai penelitian mengenai good corporate governance diantaranya ukuran dewan komisaris, proporsi komisaris independen dan komite audit (Yasser, et al. 2011, Fidanoski, et al. 2013 dan Peters \& Bagshaw 2014). Tumirin (2007), menyatakan adanya penerapan mekanisme Good Corporate Governance akan mempengaruhi tercapainya nilai perusahaan. Suatu perusahaan tentunya harus dapat memastikan kepada para penanam modal terhadap dana yang ditanamkan untuk kegiatan pembiayaan, investasi dan pertumbuhan perusahaan digunakan secara tepat dan seefisien mungkin serta memastikan bahwa manajemen bertindak yang terbaik untuk ke-pentingan perusahaan. Ionescu (2012) menyatakan bahwa perusahaan-perusahaan di Venezuela dapat mengurangi biaya modal dan dapat meningkatkan nilai pasar ketika menjalankan praktek penerapan mekanisme Good Corporate Governance. Silveira \& Barros (2006) dalam kajiannya menunjukkan adanya pengaruh 
kualitas Good Corporate Governance yang positif dan signifikan terhadap nilai pasar perusahaan.

Indikator Good Corporate Governance menggunakan Dewan komisaris. Dewan komisaris merupakan mekanisme pengendalian intern tertinggi yang bertanggung jawab untuk memonitor tindakan manajemen puncak. Komposisi individu yang bekerja sebagai anggota dewan komisaris merupakan hal penting dalam memonitor aktivitas manajemen secara efektif (Fama \& Jesen, 1983). Dewan komisaris yang berasal dari luar perusahaan, akan dipandang lebih baik karena pihak dari luar akan menetapkan kebijakan yang berkaitan dengan perusahaan dengan lebih objektif dibanding perusahan yang memiliki susunan dewan komisaris yang hanya berasal dari dalam perusahaan.

Coller \& Gregory (1999) menyatakan bahwa semakin banyak jumlah anggota dewan komisaris, maka akan semakin mudah untuk mengendalikan CEO dan monitoring yang dilakukan akan semakin efektif. Jika dikaitkan dengan pengungkapan tanggung jawab sosial, tekanan terhadap manajemen juga akan semakin besar untuk mengungkapkannya. Sitepu \& Hasan (2008) menyimpulkan bahwa semakin banyak jumlah anggota dewan komisaris, maka semakin mudah untuk mengendalikan CEO dan monitoring yang dilakukan akan semakin efektif, sehingga dapat meningkatkan luas pengungkapan sosialnya. Hasil yang sama ditunjukan oleh Rustiarini (2010) menemukan bahwa pengungkapan CSR, corporate governance berpengaruh positif terhadap nilai perusahaan serta corporate governance (kepemilikan manajerial, kepemilikan institusional, proporsi komisaris independen, dan jumlah anggota komite audit) merupakan variabel pemoderasi pada pengaruh pengungkapan CSR terhadap nilai perusahaan.

$\mathrm{H}_{2}$ : Good Corporate Governance memoderasi pengaruh antara CSR terhadap nilai perusahaan.

Ukuran perusahaan merupakan variabel penduga yang banyak digunakan untuk menjelaskan variasi pengungkapan dalam laporan tahunan perusahaan. Hal ini jika dikaitkan dengan teori agensi, perusahaan besar yang memiliki biaya keagenan yang lebih besar akan mengungkapkan informasi yang lebih luas untuk mengurangi biaya keagenan tersebut. Di samping itu, perusahaan yang berukuran lebih besar cenderung memiliki public demand akan informasi yang lebih tinggi dibanding perusahaan yang berukuran lebih kecil. Alasan lain adalah perusahaan besar dan memiliki biaya keagenan yang lebih besar tentu akan mengungkapkan informasi yang lebih luas hal ini dilakukan untuk mengurangi biaya keagenan yang dikeluarkan. Lebih banyak pemegang saham, berarti memerlukan lebih banyak juga pengungkapan. Hal ini dikarenakan tuntutan dari para pemegang saham dan para analis pasar modal (Gunawan, 2000).

Pengaruh ukuran perusahaan terhadap pengungkapan corporate social responsibility dilakukan oleh Hackston \& Milne (1996) menemukan bukti bahwa ukuran perusahaan berpengaruh positif terhadap corporate social responsibility. Irnawati (2012) menyimpulkan bahwa ukuran perusahaan dapat meningkatkan pengaruh CSR terhadap nilai perusahaan. Begitu juga, Weshah, R.Sulaiman, et al. (2012) menyimpulkan bahwa ukuran perusahaan (bank) dan tingkat risiko di bank memoderasi pengaruh CSR terhadap kinerja keuangan. Hasil yang berbeda 
ditunjukan oleh Retno \& Priantinah (2012) menyimpulkan bahwa pengungkapan CSR berpengaruh positif dan tidak signifikan terhadap nilai perusahaan dengan variabel kontrol ukuran perusahaan. Fauzi, H., et al (2007) bahwa ukuran perusahaan tidak mampu memoderasi pengaruh CSR terhadap kinerja perusahaan, artinya perusahaan besar lebih banyak melakukan kegiatan CSR dibanding perusahaan kecil. Perusahaan yang berada pada situasi survival, keuntungan yang diperoleh relatif kecil, sehingga secara logis akan lebih memilih aktivitas marketing daripada CSR (Handoyo, 2008).

$\mathrm{H}_{3}$ : Ukuran perusahaan memoderasi pengaruh antara CSR terhadap nilai perusahaan.

Berdasarkan latar belakang yang telah diuraikan, menarik untuk melakukan analisis tentang pengaruh CSR terhadap nilai perusahaan dengan menguji Good Corporate Governance dan ukuran perusahaan sebagai variabel moderating.

Perumusan hipotesis berdasakan rancangan penelitian yang dibuat dengan mengacu pada konsep teori yang digunakan dan didukung dengan penelitian terdahulu. Variabel CSR diperkirakan memiliki pengaruh terhadap nilai perusahaan yang diperkuat oleh ukuran perusahaan dan GCG. Rancangan penelitian yang dibuat sebagai berikut:

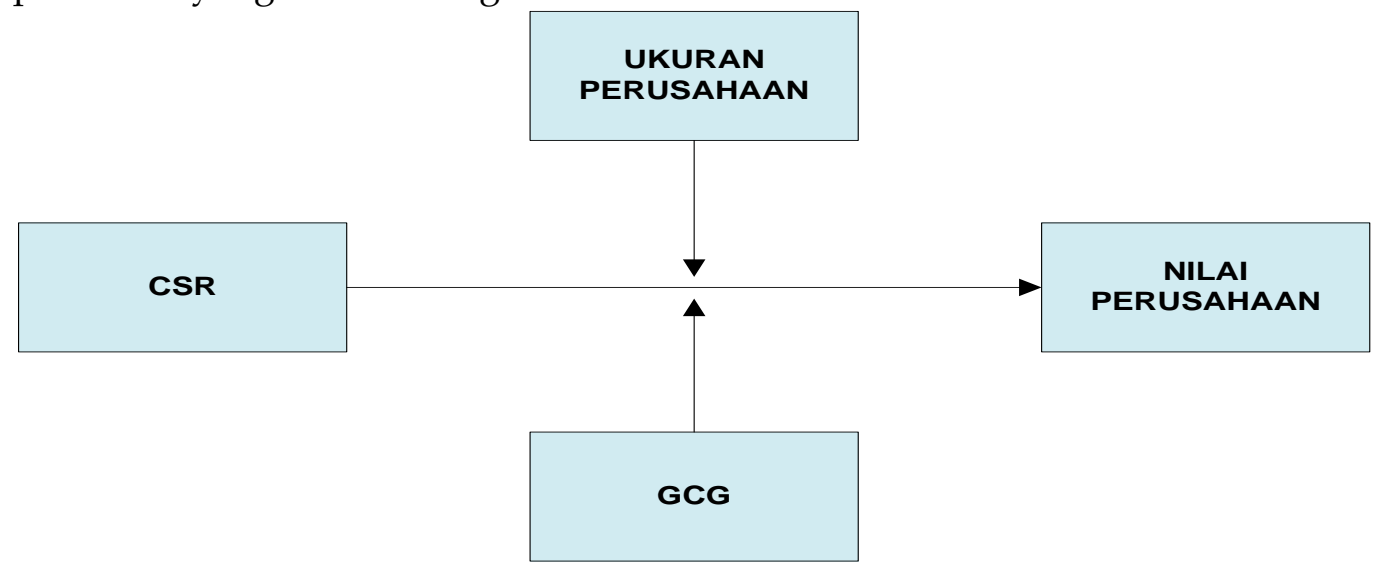

Gambar 1. Model Penelitian

Sumber: Kerangka Berpikir Penelitian, 2018

\section{METODE PENELITIAN}

Corporate social responsibility adalah suatu tindakan atau konsep yang dilakukan oleh perusahaan (sesuai kemampuan perusahaan tersebut) sebagai bentuk tanggung jawab mereka terhadap sosial/lingkungan sekitar tempat perusahaan itu berada. Pengungkapan corporate social responsibility diukur menggunakan Corporate Social Responsibility Index (CSRI) yang akan dinilai dengan membandingkan jumlah pengungkapan yang dilakukan oleh perusahaan dengan jumlah pengungkapan yang diisyaratkan. Berdasarkan peraturan BAPEPAM No.VIII.G.2 tentang laporan tahunan dan kesesuaian item untuk diaplikasikan di Indonesia, terdapat 78 item pengungkapan yang sesuai untuk diterapkan di Indonesia (Hackston \& Milne :1996 \& Sembiring :2005). Setiap item CSRI yang diungkapkan akan diberi nilai 1 dan apabila tidak diungkapkan, akan 
diberi nilai 0. Perhitungan Indeks Luas Pengungkapan CSR dirumuskan sebagai berikut:

$$
\mathrm{CSRI}_{\mathrm{t}}=\frac{\text { Jumlah item yang diungkapkan }}{78}
$$

Penerapan dan pengelolaan Good Corporate Governance yang baik adalah sebuah konsep yang menekankan pentingnya hak pemegang saham untuk memperoleh informasi dengan benar, akurat dan tepat waktu. Disamping itu juga menunjukkan kewajiban perusahaan untuk mengungkapkan semua informasi kinerja keuangan perusahaan secara akurat, tepat waktu dan transparan. Good Corporate Governance pada penelitian ini diproksi dengan Jumlah dewan komisaris yaitu jumlah personal yang menduduki jabatan dewan komisaris di setiap perusahaan (Beiner, et al. 2003). Jumlah dewan komisaris yang digunakan dalam penelitian ini adalah jumlah anggota dewan komisaris suatu perusahaan.

Ukuran Perusahaan adalah besar kecilnya perusahaan. Dengan ukuran perusahaan, maka dapat diketahui skala dimana perusahaan dapat diklasifikasikan besar, sedang, dan kecil. Pengukuran ukuran perusahaan diukur dengan total aktiva yang dimiliki perusahaan. Pengukuran variabel ukuran perusahaan mengacu pada Hackston \& Milne (1996).

Nilai perusahaan merupakan persepsi investor terhadap tingkat keberhasilan perusahaan yang sering dikaitkan dengan harga saham. Nilai perusahaan merupakan rasio pasar yang digunakan untuk mengukur kinerja harga pasar saham terhadap nilai bukunya. Ang (1997) secara sederhana menyatakan bahwa PBV merupakan rasio pasar yang digunakan untuk mengukur kinerja harga pasar saham terhadap nilai bukunya. PBV (price book value) dirumuskan sebagai berikut :

$$
\mathrm{PBV}=\frac{H \arg \text { a saham perlembar saham }}{\text { Nilaibuku perlembar saham }}
$$

Data yang digunakan merupakan data sekunder yang diambil dari laporan tahunan perusahaan Go public di bursa efek indonesia.Populasi yang digunakan dalam penelitian ini sebanyak 171 perusahaan yang termasuk dalam kategori perusahaan high profile yang terdaftardi Bursa Efek Indonesia periode 2018. Teknik pengambilan sampel dengan metode purposive sampling. Adapun karakteristik sampel penelitian ini disajikan dalam tabel sebagai berikut:

Tabel 2. Karakteristik sampel

\begin{tabular}{lll}
\hline No & Kriteria & $\begin{array}{l}\text { Jumlah } \\
\text { Perusahaan }\end{array}$ \\
\hline 1 & $\begin{array}{l}\text { Perusahaan yang termasuk dalam kategori perusahaan high } \\
\text { profile dan terdaftar di BEI per 31 Desember 2018 }\end{array}$ & 171 \\
2 & $\begin{array}{l}\text { Perusahaan yang tidak menyajikan laporan keuangan tahunan } \\
\text { dengan lengkap per 31 }\end{array}$ & (55) \\
$\quad \begin{array}{l}\text { Desember 2018 } \\
\text { Perusahaan yang tidak menyajikan pengungkapan CSR dalam } \\
\text { laporan tahunannya per 31 Desember 2018 }\end{array}$ & (6) \\
Total sampel & 110 \\
\hline Sumber: Data Penelitian, 2018
\end{tabular}


Penelitian ini bertujuan untuk menganalisis pengaruh Corporate Social Responsibility (CSR) terhadap nilai perusahaan dengan melibat variabel moderasi yaitu Good Corporate Governance (GCG) dan ukuran perusahaan. Pengujian dilakukan dengan menggunakan Moderated Regression Analysis (MRA) dengan tiga model persamaan yaitu:

$\mathrm{NP}=\alpha+\beta \mathrm{CSR}+\varepsilon_{1}$

$N P=\alpha+\beta_{1} C S R+\beta_{2} G C G+\beta_{3} C S R * G C G+\varepsilon_{1}$

$N P=\alpha+\beta_{1} C S R+\beta_{2} U P+\beta_{3} C S R * U P+\varepsilon_{2}$

\section{HASIL DAN PEMBAHASAN}

Hasil uji hipotesis diperoleh bukti bahwa CSR berpengaruh terhadap nilai perusahaan. Salah satu penyebab hipotesis diterima yaitu kemungkinan dikarenakan oleh ketaatan perusahaan-perusahaan yang tergolong high profile dalam menjalankan amanat undang undang No. 40 tahun 2007 tentang perseroan terbatas, dimana salah satu pasalnya mewajibkan perusahaan untuk mengungkapkan aktivitas tanggung jawab sosial dalam laporan tahunan meskipun item-item CSR yang diungkapkan perusahaan merupakan informasi yang masih bersifat sukarela (voluntary). Dengan dikeluarkannya aturan tersebut berarti baik perusahaan ukuran kecil maupun besar wajib melakukan pengungkapan CSR dalam laporan tahunannya. Kepatuhan suatu perusahaan menjalankan UU yang dikeluarkan pemerintah menunjukkan bahwa perusahaan sudah melaksanakan transparansi informasi untuk publik sehingga kedepan dapat menghindari perusahaan dari sanksi hukum yang telah ditetapkan. Darwin (2004) mengatakan bahwa CSR merupakan usaha perusahaan untuk menyeimbangkan komitmen-komitmennya memajukan operasional perusahaan terhadap kelompok-kelompok dan individual-individual dalam lingkungan perusahaan tersebut, termasuk didalamnya adalah pelanggan, perusahaanperusahaan lain, para karyawan, dan investor. Pembuktikan komitmen yang kuat tersebut melalui program dan laporan CSR, maka para stakeholder (termasuk para investor) akan dapat menaruh kepercayaan pada suatu perusahaan sehingga para investor berani membeli saham perusahaan meskipun dengan harga yang lebih tinggi. Jika harga saham suatu perusahaan tinggi maka

Price Book Value (PBV) juga akan naik yang mencerminkan nilai perusahaan yang baik. Weston \& Brigham (2000) mengatakan bahwa perusahaan yang berjalan dengan baik, umumnya memiliki rasio price book value di atas satu (tinggi), yang menunjukkan bahwa nilai pasar saham lebih besar dari nilai bukunya. Price book value yang tinggi membuktikan tingkat kemakmuran para pemegang saham, kemakmuran bagi pemegang saham merupakan tujuan utama dari perusahaan. Salah satu teori yang mendasari pengungkapan CSR adalah teori legitimasi. Umumnya pengungkapan tanggung jawab sosial perusahaan dilakukan untuk mendapatkan nilai positif dan legitimasi dari masyarakat. Jika citra perusahaan baik dipublik, setidaknya perusahaan mempunyai peluang yang besar dalam melakukan operasional perusahaan dalam kurun waktu yang lebih panjang dan dapat mendatangkan keuntungan untuk mensejahterakan para stakeholder dengan begitu nilai perusahaan dapat meningkat. Barkemeyer (2007) menjelaskan tentang kekuatan teori legitimasi organisasi dalam konteks 
tanggung jawab sosial perusahaan di negara berkembang yaitu tentang kapabilitas untuk menempatkan motif maksimalisasi keuntungan, membuat gambaran lebih jelas tentang motivasi perusahaan memperbesar tanggung jawab sosialnya. Selain itu, legitimasi organisasi dapat memasukkan faktor budaya yang membentuk tekanan institusi yang berbeda dalam konteks yang berbeda. Hadi (2011) berpendapat bahwa legitimasi organisasi dapat dilihat sebagai sesuatu yang diberikan masyarakat kepada perusahaan dan sesuatu yang diinginkan atau dicari perusahaan dari masyarakat. Dengan demikian, legitimasi merupakan manfaat atau sumber daya potensial bagi perusahaan untuk bertahan hidup (going concern) dalam proses operasionalnya.

Tabel 3. hasil uji multikolonieritas

\begin{tabular}{llll}
\hline & & \multicolumn{2}{l}{ Collinearity Statistics } \\
\cline { 3 - 4 } Model & & Tolerance & VIF \\
\hline 1 & (Constant) & & \\
CSR & .799 & 1.251 \\
GCG & .659 & 1.516 \\
& Ukuran Perusahaan & .635 & 1.575 \\
& & & \\
a. Dependent Variable: Nilai perusahaan & &
\end{tabular}

Sumber: Data Penelitian, 2018

Menurut Hackson \& Milne (1996), perusahaan yang berorientasi pada konsumen diperkirakan akan memberikan informasi mengenai pertanggungjawaban sosial karena dapat meningkatkan image perusahaan. Semakin banyak informasi sosial dan lingkungan yang disampaikan oleh suatu perusahaan maka investor akan cenderung berinvestasi kepada perusahaan tersebut yang akan berdampak pada meningkatnya nilai perusahaan. Sementara menurut Matteww Brine (2008) bahwa Corporate social responsibility dapat memberikan kontribusi terhadap kinerja keuangan. Hal ini dikarenakan dalam pengambilan keputusan, perusahaan harus mempertimbangkan berbagai masalah sosial dan lingkungan jika perusahaan ingin memaksimumkan hasil keuangan jangka panjang yang nantinya dapat meningkatkan nilai perusahaan. Hasil penelitian ini sejalan dengan penelitian Gunawan \& Utami (2008), Weshah R.Sulaiman, et al. (2012), dan Balbanis, et al. (1998) yang menemukan bahwa pengungkapan CSR dalam laporan tahunan perusahaan dapat menambah nilai perusahaan yang dibuktikan dengan meningkatnya harga saham suatu perusahaan.

Nilai tolerance terkecil sebesar 0.635 . artinya tidak ada variabel independen yang memiliki nilai tolerance lebih kecil dari 0,10. Berarti tidak terjadi multikolonieritas antar variabel independen.

Nilai Kolmogorov-Smirnov sebesar 0.645 dan tingkat probabilitas signifikansi diatas 0.05 yaitu sebesar 0.860 . hal ini mengindikasikan bahwa data residual terdistribusi secara normal. 
Tabel 4. Hasil Uji Normalitas

\begin{tabular}{lll}
\hline & & Unstandardized Residual \\
\hline $\mathrm{N}$ & & 110 \\
Normal Parametersa & Mean & .0000000 \\
& Std. Deviation & 1.6611 \\
Kolmogorov-Smirnov Z & & .645 \\
Asymp. Sig. (2-tailed) & & .860 \\
\hline
\end{tabular}

Sumber: Data Penelitian, 2018

Besarnya nilai $\mathrm{R}$ Square sebesar 0,104 . Nilai ini menerangkan besarnya kontribusi variabel CSR yang mampu menjelaskan nilai perusahaan hanya sebesar 10,4\% sedangkan 89,6\% dijelaskan oleh variabel diluar model.

Tabel 5. Hasil Uji Koefisien Determinasi Struktur 1

\begin{tabular}{llll}
\hline Model & $\mathrm{R}$ & R Square & Adjusted R Square \\
\hline 1 & $.322^{\mathrm{a}}$ & .104 & .095
\end{tabular}

a. Predictors: (Constant), CSR

Sumber: Data Penelitian, 2018

Nilai signifikansi CSR sebesar 0,001 (lebih kecil dari 0,05) dan nilai koefisien beta sebesar 0,322. Berarti CSR berpengaruh terhadap nilai perusahaan (hipotesis pertama diterima).

Tabel 6. Hasil Uji t

\begin{tabular}{lllll}
\hline Model & & Beta & $\mathrm{t}$ & Sig. \\
\hline 1 & (Constant) & & -.527 & .599 \\
& CSR & .322 & 3.537 & .001
\end{tabular}

a. Dependent Variable: Nilai perusahaan

Sumber: Data Penelitian, 2018

Nilai R Square sebesar 0,188 atau sekitar 18,8\%. Dengan demikian, Nilai ini membuktikan bahwa CSR dapat dimoderasi oleh GCG terhadap nilai perusahaan $(18,8 \%>10,4 \%)$.

Tabel 7. Hasil Uji Koefisien Determinasi Struktur 2

\begin{tabular}{llll}
\hline Model & $\mathrm{R}$ & R Square & Adjusted R Square \\
\hline 1 & $.434^{\mathrm{a}}$ & .188 & .165
\end{tabular}

a. Predictors: (Constant), CSR*GCG, GCG, CSR

Sumber: Data Penelitian, 2018

Nilai R Square sebesar 0,405 atau sekitar 40,5\%. Dengan demikian, Nilai ini membuktikan bahwa CSR dapat dimoderasi oleh ukuran perusahaan terhadap nilai perusahaan $(40,5 \%>10,4 \%)$.

Tabel 8. Hasil Uji Koefisien Determinasi struktur 3

\begin{tabular}{llll}
\hline Model & $\mathrm{R}$ & R Square & Adjusted R Square \\
\hline 1 & $.636^{\mathrm{a}}$ & .405 & .388
\end{tabular}

a. Predictors: (Constant), CSR*Ukuran perusahaan, CSR, Ukuran Perusahaan

Sumber: Data Penelitian, 2018

Hasil uji hipotesis menemukan bahwa GCG yang diproksikan dengan dewan komisaris mampu memoderasi pengaruh CSR terhadap nilai perusahaan. Penerapan dan pengelolaan Good Corporate Governance yang baik adalah sebuah 
konsep yang menekankan pentingnya hak pemegang saham untuk memperoleh informasi dengan benar, akurat dan tepat waktu. Disamping itu juga menunjukkan kewajiban perusahaan untuk mengungkapkan semua informasi kinerja keuangan perusahaan secara akurat, tepat waktu dan transparan. Oleh karena itu, baik perusahaan publik maupun tertutup harus memandang Good Corporate Governance (GCG) bukan hanya sebagai aksesoris belaka, namun sebagai upaya peningkatan kinerja dan nilai perusahaan (Tjager, 2003).

Menurut Organizational for Economic Co-operation and Development (OECD) (1998) GCG yaitu seperangkat peraturan yang mengatur hubungan antara pemegang saham, pengelola perusahaan, pihak kreditur, pemerintahan, karyawan dan para pemegang kepentingan intern dan ekstern lainnya yang berkaitan dengan hak-hak dan kewajiban atau dengan kata lain merupakan suatu sistem yang mengatur dan mengendalikan perusahaan. Artinya bahwa dalam pengelolaan perusahaan di perlukan adanya peraturan yang jelas yang memuat hak dan kewajiban dari masing-masing pihak yang terkait (manajemen, kreditur, pemegang saham, masyarakat, pemerintahan dan sebagainya) sehingga masing-masing dapat menjalankan tugasnya dengan baik untuk mencapai tujuan organisasi. Herwidiyatmo (2000) menyatakan bahwa GCG merupakan proses dan struktur yang dapat digunakan untuk mengarahkan kegiatan dan mengelola bisnis perusahaan ke arah peningkatan pertumbuhan bisnis dan akuntabilitas perusahaan. Adapun tujuan akhirnya adalah meningkatkan kemakmuran pemegang saham dalam jangka panjang, dengan tetap memperhatikan kepentingan stakeholders lainnya. Dewan komisaris merupakan salah satu bagian dari GCG. Muliyadi (2010) mengatakan bahwa dewan komisaris terdiri dari inside dan outside director yang akan memiliki akses informasi khusus yang berharga dan sangat membantu dewan komisaris serta menjadikannya sebagai alat efektif dalam keputusan pengendalian. Sementara fungsi dewan komisaris adalah mengawasi pengelolaan perusahaan yang dilaksanakan oleh manajemen (direksi) dan bertanggungjawab untuk menentukan apakah manajemen memenuhi tanggungjawabnya dalam mengembangkan dan menyelenggarakan pengendalian intern perusahaan. Menurut Coller \& Gregory (1999), semakin banyak jumlah anggota dewan komisaris, maka akan semakin mudah untuk mengendalikan CEO dan monitoring yang dilakukan akan semakin efektif. Jika dikaitkan dengan pengungkapan tanggung jawab sosial, tekanan terhadap manajemen juga akan semakin besar untuk mengungkapkannya. Artinya keberadaan dewan komisaris mampu mengendalikan manajemen untuk melakukan pengungkapan laporan CSR yang luas sehingga mampu meningkatkan kinerja perusahaan dan juga mempengaruhi nilai perusahaan. Sitepu \& Hasan (2008) menyimpulkan bahwa semakin banyak jumlah anggota dewan komisaris, maka semakin mudah untuk mengendalikan CEO dan monitoring yang dilakukan akan semakin efektif, sehingga dapat meningkatkan luas pengungkapan sosialnya. Hasil penelitian ini sejalan dengan penelitian yang dilakukan Rustiarini (2010) yang menyimpulkan bahwa keberadaan GCG mampu memperkuat pengaruh CSR terhadap nilai perusahaan.

Berdasarkan hasil uji hipotesis, ukuran perusahaan juga mampu memoderasi hubungan antara pengaruh CSR terhadap nilai perusahaan. Ukuran 
perusahaan merupakan skala yang menentukan besar atau kecilnya perusahaan. Semakin besar ukuran perusahaan, maka sumber informasi perusahaan yang tersedia semakin baik dan luas serta mudah diakses oleh publik. Umumnya perusahaan besar akan mengungkapkan informasi lebih banyak dari pada perusahaan kecil disebabkan kegiatan yang dilakukan perusahaan besar biasanya lebih banyak dan variatif serta dukungan dana maupun sumber daya yang lebih memadai. Selain itu, perusahaan besar akan menghadapi risiko politis yang lebih besar dibanding perusahaan kecil. Perusahaan yang lebih besar mungkin akan memiliki pemegang saham lebih banyak yang memperhatikan program sosial yang dibuat perusahaan dalam laporan tahunan dan merupakan media untuk menyebarkan informasi tentang corporate social responsibility dan lingkungan perusahaan (Untari, 2010).

Semakin besar ukuran perusahaan, maka semakin banyak informasi yang diungkapkan dan hal ini akan berdampak pada peningkatan nilai perusahaan. Jika hal ini dikaitkan dengan teori agensi, perusahaan besar memiliki biaya keagenan lebih besar akan mengungkapkan informasi lebih luas untuk mengurangi biaya keagenan tersebut. Di samping itu perusahaan besar merupakan emiten yang banyak disoroti, maka pengungkapan yang lebih luas merupakan salah satu usaha untuk mengurangi biaya politis sebagai wujud tanggung jawab sosial perusahaan. Selain itu, perusahaan yang berukuran lebih besar cenderung memiliki public demand akan informasi yang lebih tinggi dibanding perusahaan yang berukuran lebih kecil. Oleh karena itu, perusahaan besar dan memiliki biaya keagenan yang lebih besar tentu akan mengungkapkan informasi yang lebih luas dengan tujuan untuk mengurangi biaya keagenan yang dikeluarkan. Lebih banyak pemegang saham, berarti memerlukan lebih banyak juga pengungkapan. Hal ini dikarenakan tuntutan dari para pemegang saham dan para analis pasar modal (Gunawan, 2000). Hasil temuan ini sejalan dengan penelitian Weshah, et al. (2012) yang melakukan riset pada perusahaan perbankkan menemukan bahwa ukuran perusahaan dan tingkat risiko di bank memoderasi pengaruh CSR terhadap kinerja keuangan. Begitu juga dengan hasil penelitian dari Irnawati (2012) yang menyimpulkan bahwa ukuran perusahaan dapat meningkatkan atau memperkuat hubungan pengaruh CSR terhadap nilai perusahaan.

\section{SIMPULAN}

Berdasarkan hasil pengujian dan analisis data yang dilakukan dapat di peroleh hasil penelitian dan menyimpulkan bahwa CSR berpengaruh terhadap nilai perusahaan, GCG mampu memoderasi hubungan antara CSR dengan nilai perusahaan, begitu juga dengan ukuran perusahaan yang mampu memoderasi hubungan pengaruh CSR terhadap nilai perusahaan.

Bagi perusahaan yang mengharapkan nilai perusahaan meningkat diharapkan untuk tetap konsisten dalam membuat laporan CSR yang lebih luas dengan memaksimalkan fungsi pengawasan dewan komisaris baik dalam keadaan posisi laba perusahaan meningkat ataupun menurun serta perusahaan dengan skala kecil maupun besar. Karena investor saat ini tidak hanya melihat kesuksesan perusahaan dari segi keuangan saja tetapi faktor non keuangan seperti CSR menjadi daya tarik tersendiri untuk saat ini karena hal tersebut juga 
bisa menjadi refrensi keberlangsungan perusahaan untuk periode yang akan datang terutama hubungan perusahaan dengan lingkungan dan masyrakat sekitar. Investor tidak hanya melihat skala perusahaan besar maupun kecil untuk mengambil keputusan dalam berinvestasi tetapi lebih menyorot manajemen perusahaan dan seberapa besar jaminan keamanan perusahaan melakukan proses produksi dengan lingkungan sekitar nya.

Bagi peneliti selanjutnya, mengingat implikasi dari kegiatan maupun laporan pengungkapan CSR tidak langsung bisa dirasakan. Untuk itu diharapkan menggunakan periode data dua tahun atau lebih (timeseries) untuk melihat implikasi pengungkapan CSR yang lebih baik dan juga menganalisis perusahaan yang low profile. Dalam mengukur variabel penelitian, peneliti hanya menggunakan satu indikator tiap variabel, peneliti selanjutnya diharapkan menambah alat ukur untuk masing-masing variabel dan menggunakan alat analisis data struktur equation modeling (SEM) sehingga hasil penelitian lebih luas.

\section{REFERENSI}

Ahmed, P., \& Nanda, S. (2000). Style Investing : Incorporating Growth Characteristics in Value Stocks. The Journal of Portfolio Management, Vol. 27, No. 3. p. 1-27.

Ali, I. (2010). Pelaporan Keuangan dan Asimetri Informasi dalam Hubungan Agensi. Jurnal Lintasan Ekonomi, Vol.XIX, No.2.

Alijoyo, A., \& Zaini, S. (2004). Komisaris Independen, Penggerak Praktik GCG di Perusahaan, Penerbit PT Indeks, Jakarta.

Ang, R. (1997). Buku Pintar Pasar Modal Indonesia. Mediasoft Indonesia: Jakarta.

Arifin, S. (2002). An Empyrical Analysis of The Relation Between The Board of Director's Composition an the level of Voluntary Disclosure., Prooceedings For The Fifth Indonesian Conference On Accounting, No. 5 p. 46-57.

Arikunto, S. (2006). Prosedur Penelitian (Suatu Pendekatan Praktik), Edisi revisi kelima, PT Rineka Cipta, Jakarta.

Balbanis, G., C, P., \& J, L. (1998). Corporate Social Responsibility and economic performance in the top British companies: are they linked?, European Business Review, Vol 98 No.1, pp. 25-44.

Barkemeyer, R. (2007). Legitimacy as a Key Driver and Determinant of CSR in Developing Countries. Paper for the 2007 Marie Curie Summer School on Earth System Governance, 28 May-06 June 2007, Amsterdam.

Collier, P., \& Gregory, A. (1999). Audit Committee Activity and Agency Costs, Journal of Accounting and Public Policy, Vol 18 (4-5) pp 311-332.

Cowen, S. S., Ferreri, L. B., \& Parker, L. D. (1987). "The Impact of Corporate Characteristics On Social Responsibility Disclosure: A Typology And Frequency-Based Analysis", Accounting, Organisations and Society, Vol. 12 No. 2, p. 111-22.

Eisenhardt, K. M. (1989). Agency Theory: An Assesment and Review. Academy of management Review, 14, hal 57-74.

Euis, \& Taswan. (2002). Pengaruh Kebijakan Hutang Terhadap Nilai Perusahaan Serta Beberapa Faktor Yang Mempengaruhinya. Jurnal Bisnis dan Ekonomi. Vol. 8, No.1.hal. 8-16. . 
Fauzi, M., \& Rahman. (2007). The Link between Corporate Social Performance and Financial Performance: Evidence from Indonesian Companies. Issues in Social and Environmental Accounting, Vol. 1, No. 1, pp. 149-159.

Ferdinand, A. (2006). Metode Penelitian Manajemen. Edisi Kedua, Universitas Diponegoro, Semarang.

Gapensi, B. (1996). Intermediate Financial Management, Fifth Edition, The Dryden Press, New York.

Gray, R., Dey, C., Owen, D., Evans, R., \& Zadek, S. (1997). Struggling with the Praxis of Social Accounting: Stakeholders, Accountability, Audits and Procedures. Accounting, Auditing and Accountability Journal. Vol. 10, No. 3, p. 325-364.

Gray, R., Kouhy, R., \& Lavers, S. (1995). Corporate Social and Environmental Reporting: A Review of Literature and a Longitudinal Study of UK Disclosure. Accounting, Auditing and Accountability Journal. Vol. 8, No. 2, p. 47-77.

Gray, R., Kouhy, R., \& Lavers, S. (1995). Methodological Themes: Constructing a Research Database of Social and Environmental Reporting by UK Companies. Accounting, Auditing and Accountability Journal. Vol. 8, No. 2, p. 78-101.

Gray, R., Owen, D., \& Maunders, K. (1987). Corporate Social Reporting: Emerging Trends in Accountability and the Social Contract. Accounting, Auditing and Accountability Journal. Vol. 1, No. 1, p. 6- 20.

Gujarati, D. (1992). Ekonometrika Dasar, diterjemahkan oleh Sumarno Zain, Jakarta: Erlangga.

Gunawan, \& Utami. (2008). Peranan Corporate Social Responsibility dalam Nilai Perusahaan. Jurnal Akuntansi dan Keuangan, Volume 7, Nomor 2.

Gunawan, \& Yuniati. (2002). Analisis Pengungkapan Informasi Laporan Tahunan Pada Perusahaan Yang Terdaftar Di Bursa Efek Jakarta. Jurnal Akuntansi dan Keuangan, Volume 7, Nomor 2.

Guthrie, J., \& Parker, L. D. (1990). “Corporate Social Disclosure Practice: A Comparative International Analysis", Advances in Public Interest Accounting, Vol. 3, p. 159-175.

Hackston, D., \& Markus, J. M. (1996). Some Determinants of Social and Environmental Disclosure in New Zealand Companies. Accounting, Auditing and Accountability Journal. Vol. 9, No. 1, p. 77-108.

Haniffa, R. M., \& E, C. T. (2005). The Impact of Culture and Governance on Corporate Social Reporting, Journal of Accounting and Public Policy 24, pp. 391-430.

Haris, W. (2004). Pengaruh Earnings Management Terhadap Kinerja Di Seputar SEO. Tesis S2. Magister Sains Akuntansi UNDIP. Tidak dipublikasikan.

Hartono, J. (2000). Teori Portofolio dan Analisis Investasi. Edisi Pertama. Yogyakarta . BPFE.

Hasibuan, R. (2001). "Pengaruh Karakteristik Perusahaan Terhadap Pengungkapan Sosial" Tesis, Universitas Diponegoro, Semarang.

Hidayati, \& Murni, S. (2009). Pengaruh Pengungkapan Corporate Social Responsibility Terhadap Earningss Response Coefficient Pada Perusahaan High Profile. Jurnal Bisnis dan Akuntansi, Vol. 11, No. 1.hal 1-18. 
Husnan, S. (2000). Manajemen Keuangan Teori dan Penerapan (Keputusan Jangka Panjang). Yogyakarta : BPFE.

Jensen, C. M. (1993). The Modern Industrial Revolution, Exit, and The Failure of Internal Control Systems. Journal of Finance, 48, 831-380.

Keown. (2004). Manajemen Keuangan : Prinsip-Prinsip dan Aplikasi. Edisi 9, Indeks. Jakarta.

Keraf, A. S. (1997). Etika Lingkungan,Penerbit Buku Kompas, Jakarta.

Lipton, M., \& Jay, W. L. (1992). A Modest Proposal for Improves Corporate Governance. Business Lawyer, 48 (1), 59-77.

Mahoney, L. S., \& Linda, T. (2006). An Examination of the Structure of Executive Compensation and Corporate Social Responsibility: A Canadian Investigation. Journal of Business Ethics, 69:149-162.

Mahoney, L. S., \& Linda, T. (2005). Corporate Social Responsibility And LongTerm Compensation: Evidence From Canada. Journal of Business Ethics, 57: 241-253.

Mardi. (2016). Faktor - Faktor Yang Mempengaruhi Nilai Perusahaan Melalui Corporate Social Responsibility (CSR). ISSN: 2302-8556. E-Jurnal Akuntansi Universitas Udayana Vol.26.2.Februari (2019): 1518-1544.

Martono, \& Harjito, A. (2005). Manajemen Keuangan. Penerbit Ekonisia: Yogyakarta.

Mathews, M. R. (1997). Twenty-Five Years of Social and Environmental Accounting Research: Is there a Silver Jubilee to Celebrate? Accounting, Auditing and Accountability Journal. Vol. 10, No. 4, p. 481-531.

Mukhlasin. (2002). Analisis Pemilihan Metode Akuntansi Persediaan berdasarkan Richardian Hipotesis. Vol. 2, No. 1. hal. 21-39.

Mulyadi. (2002). Auditing: Jilid 1 Edisi Enam, Salemba Empat, Jakarta.

Patten, D. M. (1991). Exposure, Legitimacy, And Social Disclosure, Journal of Accounting and Public Policy, Vol. 10, pp. 297-308.

Patten, D. M. (1992). Intra-Industry Environmental Disclosures In Response To The Alaskan Oil Spill: A Note On Legitimacy Theory, Accounting, Organisations and Society, Vol. 17 No. 5, pp. 471-5.

Pflieger, J., Fischer, M., Kupfer, T., \& Eyerer, P. (2005). The Contribution of Life Cycle Assessment to Global Sustainability Reporting of Organization. Management of Environmental, 16.

Raar, J. (2004). Environmental and Social Responsibillity: A Normative Financial Reporting Concept. The Fouth Asia Pasific Interdiciplinary Research in Accounting (Apira), Conference, Singapore.

Retno, \& Priantinah. (2012). Pengaruh Good Corporate Governance Dan Pengungkapan Corporate Social Responsibility Terhadap Nilai Perusahaan (Studi Empiris Pada Perusahaan Yang Terdaftar di Bursa Efek Indonesia periode 2007-2010). Jurnal Nominal, Volume I, N.

Rustiarini, N. W. (2010). Pengaruh Corporate Governance pada Hubungan Corporate Social Responsibility dan Nilai Perusahaan. Jurnal Ilmiah Akuntansi Dan Bisnis, Vol 6, No. 1. .

Salvatore, D. (2005). Ekonomi Manajerial dalam Perekonomian Global. Salemba Empat: Jakarta. 
Sayekti, Y., \& Ludovicus, S. W. (2007). Pengaruh CSR Disclosure Terhadap Earning Response Coefficient (Suatu Studi Empiris Pada Perusahaan Yang Terdaftar Di Bursa Efek Jakarta). Jurnal Akuntansi \&. Keuangan. Volume 7 Nomor 2.

Sitepu, A. C., \& Hasan, B. S. (2008). Faktor-Faktor yang Mempengaruhi Pengungkapan Informasi Sosial dalam Laporan Tahunan pada Perusahaan Manufaktur yang Terdaftar Di Bursa Efek Jakarta. Jurnal Akuntansi 19: 01-09.

Sugiyono. (2006). Metode Penelitian Bisnis. CV. Bandung. Alfabeta.

Sujoko, \& Ugy, S. (2007). Pengaruh Struktur Kepemilikan, Leverage, Faktor Intern, dan Faktor Ekstern Terhadap Nilai Perusahaan (Studi Empirik pada Perusahaan Manufaktur dan Non Manufaktur di Bursa Efek Jakarta). Jurnal Manajemen dan Kewirausahaan.

Sunariyah. (1997). Pengantar Pengetahuan Pasar Modal. Yogyakarta. UPP-AMP YKPN.

Suojanen, W. (1954). Accounting Theory and the Large Corporation, Accounting Review, July, dalam Raar, Jean. 2004. Environmental Accounting Responsibility: A Normative Financial Reporting Concept. The Fourth Asia Pasific Interdiciplinary Research in Accoun.

The Association of Chartered Certified Accountants (ACCA). 2004. An Introduction to Sustainability Reporting for Organisations in Indonesia. (t.thn.).

Weshah, S., Dahiyat, A.A., Awwad, M.R.A and Hajjat, E.S. 2012. The mpact of Adopting Corporate Social Responsibility on Corporate Financial Performance: Evidence from Jordanian Banks. Interdisciplinary Journal Of Contemporary Research In Business, Vol . (t.thn.).

Weston, J.F and Brigham, E.F. 2000. Dasar-dasar Manajemen Keuangan Jilid I. Jakarta : Erlangga. (t.thn.).

Wibisono, Yusuf. 2007. Membedah Konsep dan Aplikasi CSR. Gresik: Fascho Publishing. (t.thn.).

Zeghal, Daniel and Sadrudin A. Ahmed. 1990. Comparison of Social Responsibility Information Disclosure Media Used by Canadian Firms. Accounting, Auditing and Accountability Journal. Vol. 3, No. 1, p. 9-20. (t.thn.). 